\title{
THE ETHICS OF BECOMING IN A PEDAGOGY FOR SOCIAL JUSTICE. A POSTHUMANIST PERSPECTIVE
}

\section{Postma}

Department of Education and Curriculum Studies

University of Johannesburg

Johannesburg, South Africa

e-mail: dpostma@uj.ac.za

\section{ABSTRACT}

The spate of local (\#Rhodesmustfall, \#Feesmustfall) and global (such as Occupy, Arabspring) protest movements point to the multiple forms of exclusion that characterise late Capitalism. These exclusions are not only detrimental to the majority of humans, but also to the earth. The protests at higher education institutions are directed at institutional mechanisms and pedagogies that exclude the majority from meaningful participation in defining the social and environmental good. This article is a conceptual investigation into aspects of a posthuman pedagogy that aims to define notions of sociality and justice. A pedagogy of social justice does not simply aim at the inclusion of the marginalised in the social order, but queries the ways social ordering draws on an economy of lack and desire, the very resources of transformation. It is claimed that a posthuman perspective could do justice to the becoming of humans, nonhumans and earth. Particular aspects of a pedagogy of social justice are discussed such as desire, enjoyment; becoming and responsibility. It is argued that a focus on the production of desire through which students become minoritarian could enhance their power of differential becomings and their constructive engagement in the transformation of reality.

Key words: Deleuze, Braidotti, posthumanism, pedagogy, social justice, subjectivity, becoming

\section{INTRODUCTION}

Higher education in South Africa and elsewhere is characterised by various forms of alienation, exclusion and marginalisation (Chetty and Merret 2014; Giroux 2014; Higgins 2013; Strom and Martin 2013) as highlighted in various protest movements (such as \#Feesmustfall and \#Rhodesmustfall). These are protests against higher education systems that have to a large extent become corporatised and commercialised (Alexander 2014; Apple 2006; Bok 2003; Giroux 2014; McGettigan 2013). These systems favour a subjectivity based on the idealisation of the globally mobile entrepreneurial class. Students are subjectified as 'clients' and knowledge is commodified. Marginalised groups such as black working class youth are largely excluded from formal access, experience high dropout rates or receive at most a limited set of vocational skills. Epistemological access is mainly seen as access to established modernist 
forms of knowledge rather than alternative and multiple forms of knowledge (Lyotard 1984; Zipin, Fataar and Brennan 2015). Institutional rankings impose on universities neoliberal values of competitiveness and quantifiable outcomes and produce lecturers as entrepreneurial professionals who constantly monitor themselves in terms of institutional demands (Barnett 2003). Research, largely driven by the state and commercial interests, focuses increasingly on commodified knowledge. Neoliberal forms of education produce subjectivities characterised by consumerism, isolated and possessive individualism and competitiveness essential to the reproduction of the neoliberal order (Ball 2013). In the process the status of higher education as a public good is fundamentally undermined. According to Deleuze (1995, $179 \mathrm{ff}$.) we are 'turning education into a business' as part of a system of domination through which institutions are breaking down.

This neoliberal order, where higher education is both a producer and a product, is not sustainable since it benefits a small minority at the cost of the majority of others, both human and nonhuman. While individualistic, competitive and possessive subjectivity is portrayed as the ideal for everyone, only a few fit the model. The majority are either marginalised or excluded, not only from these processes of accumulation and production, but also from the opportunity to fully participate in the means of production and the meaning of life.

In order to provide a response to the devastating effects of late Capitalism, a notion of social justice is needed that does not only protest against injustices and inequalities, but which is based on the kind of agency that could participate in the transformation of reality. The transformative agent is no longer the autonomous and rational human being. The material turn (Bennet and Joyce 2010) in social theorising identifies the limitations of humanist thinking by pointing to the entanglement of the human and the nonhuman. Transformation does therefore not only apply to the social world, but to the ecology of being itself. As a consequence social justice has to be located against a broader ecological ethic. Such a broader notion of justice is needed because the same processes of exploitation that subjugate humans and promote social injustices lead to environmental degradation, as indicated by Haraway's (2015) notion of 'multispecies ecojustice’ and elaborated on by Latour in his 'Politics of Nature' (Latour 2004a). An awareness of this entanglement leads to a conception of social justice that does not treat humans, nonhumans and the earth separately.

The global and local protest movements are a response to human and environmental injustices. A point is reached of 'not any more' because 'we do not want to be governed like that' (Foucault 2007, 44). In the sphere of higher education there is resistance to the kinds of academic subjectivities that are being produced (Ball 2015). 
Subjectivity has become, according to Ball, a central terrain of contest since it is the site where the resources for the reproduction of neoliberal ordering is secured. It is, however, not only a contest for the control of subjectivity, but a contest within subjectivity itself, that Deleuze and Guattari $(1987,215)$ call 'the fascist inside you, the fascist you yourself sustain.' While neoliberalism lays a total claim on the subject, subjectivity is always more than or different from the dominant forms of subjectification (Foucault 1982). Since education is centrally concerned with the development of the subject, a pedagogy for social justice aims to develop an ethical subjectivity that could resist and overcome neoliberal subjectifications.

In order to develop a pedagogy of social justice that could enhance such a critical and transformative subjectivity, a 'line of flight' is followed on the basis of certain concepts of Deleuze and Guattari (Deleuze 1995, 140,1; Deleuze and Guattari 1987, 9). This investigation into a pedagogy for social justice engages with the significant body of literature on the educational implications of the work of Deleuze and Guattari (Cole 2011; Duff 2013; Olsson 2009). It draws on insights of various authors (such as Carrington 2011; Gough 2004; Grellier 2013; Strom and Martin 2013) who use Deleuze and Guattari's notion of the rhizome to investigate how educators could promote alternative non-hierarchical practices and how students become in unpredictable ways. Deleuzian notions of inclusivity and engagement are investigated in relation to inclusive education (Goodley 2007) and service learning (Carrington 2011). While important insights are developed by these authors, the main point of posthumanism is to go beyond the normal/deviance binary by emphasising the productivity of difference and multiplicity. A posthumanist approach to social justice not only attends to marginalised groups (class, 'race' gender, disabilities) that are excluded from full participation, but also provides ways in which the dominant could become part of an ethic of inclusivity.

The purpose of a pedagogy for social justice in Critical Pedagogy is to interrupt the reproduction of forms of domination (Macrine, McLaren and Hill 2010) and to question the basis on which equalities are established. A posthuman approach, in contrast, is characterised by the way it draws on a positive notion of power through which reality could be enacted differently. While this approach decentres the human, the posthuman subject is not powerless. The transformative power of posthuman subjectivity is not to be found in notions of a centred subject characterised by rationality, freedom, autonomy and emancipation, but rather in the capacity to be affected and to affect others. This is also not a subjectivity to which justice has to be given, but one where a form of empowerment with and through others is inherent to an ethos of becoming. This ethos is a central focus of a pedagogy of social justice. 


\section{POSTHUMANISM}

Posthumanism provides the resources to go beyond protest in order to participate in the becoming of the world. Posthumanism could be presented as a response to the increasing social inequalities and environmental degradation. While it stays true to some humanist values such as freedom and equality, it decentres the human by overcoming binaries such as male/female, mind/body, human/animal and human/nature. This account of posthumanism draws in particular on the work of Spinoza, Foucault, Deleuze, Deleuze and Guattari, Latour and Braidotti.

\section{Subjectivity}

The use of the term 'subjectivity' instead of 'subject' represents a shift from the centred and unified subject in liberal and humanist views. Posthuman subjectivity is not an individual person or a particular identity, but the effect of processes of subjectification constituted through various forces. Deleuze $(1995,93)$ views subjectification as linked to 'an electric or magnetic field'. It is an 'individuation taking place through intensities (weak as well as strong ones), it's to do with individuated fields, not persons or identities'.

This notion of subjectivity is similar to 'actancy' in actor-network theory where the subject is a heterogeneous assemblage that has an effect (Latour 2004b). It also draws on the poststructural view of Foucault who defines the human as an effect of discursive practices of power (Foucault 1982). Posthumanism in combination with neo-materialism (Coole and Frost 2010) takes this further by locating the human within assemblages of non-human life-forces. It is also similar to Balibar's (1997) notion of ‘trans-individuality’ which emphasises subjectivity as an assemblage while avoiding individualism.

Subjectivity is not to be associated with the autonomous, rational and volitional humanist subject, but one produced within an assemblage of forces. Deleuze locates the subject accordingly within an event:

To the extent that events are actualized in us, they wait for us and invite us in .... It is a question of attaining this will that the event creates in us; of becoming the quasi-cause of what is produced in us, the Operator ... Everything was in order with the events of my life before I made them mine; to live with them is to find myself tempted to become their equal, as if they had to get from me only that which they have that is best and most perfect. (Deleuze 1990, 148).

Agential elements such as volition and desire are therefore not located within the individual but originate from the event, which precedes the human subject temporally and ontologically. Although the subject is not centred and agential, it is on the other hand not a victim of these events or forces. While they are essential, the self becoming of the subject is manifested in free 
expression and speech. The new subjectivity is manifested by expressing itself passionately and freely so as 'to bring something to life, to free life from where it's trapped, to trace lines of flight' (Deleuze 1995, 141). Subjectivity is not a substance or essence, but a nomad, a flux or a rhizome that spreads in all directions without a centre or a goal. Human subjectivity does not stand on its own, but is constituted by and tied to multiple others. Subjectivity is an ecological entity that is dependent on the forces and resources drawn from many others. It is not singular or plural, but a multiplicity. It is, for Deleuze, not a static point but a point transformed into a line through fast movement (Deleuze and Guattari 1987, 27).

The relationality, multiplicity and heterogeneity of posthuman subjectivity make it receptive to and a participant within the flux of powers in the unfolding of events.

\section{Powers}

One of the most important contributions of posthuman perspectives that originates from Spinoza and Nietzsche is the emphasis on the productive, life-affirming role of powers. Powers in the plural refers to various capacities through which reality is transformed and is contrasted with the singular dominating Power. Powers precede subjects by contributing to the processes of subjectification. The individuated subject does not have power, but find itself within power relations. Powers are the driving force in the processes of becoming. While powers are neutral in the sense that they could be actualised in different ways the joy of human life lies in the expansion of constructive and affective powers with others.

This positive conception of power is different from humanist and rationalist views where power is separated from knowledge and freedom (Berlin 1984). In contrast, we (humans, nonhumans, earth) are always part of the flow of powers, but then not as a force that dominates, but one that is closely related with desire, enjoyment and affect.

Deleuze and Guattari (1987) draw on Spinoza's distinction between two kinds of power. Potestas (pouvoir) refers to the power to control and dominate, whereas potentia (conatus, puissances) refers to the affirmative, life giving powers incited by desire and passion. They also draw on Nietzsche's understanding of power as a life-affirming force. Potentia or potentiality is creative and expressive in the striving towards actualisation. The expansion of these powers is an expression of the joy of life. Potentia, or active power, is constrained by potestas, or reactive power. Active powers enhance potentiality by extending the limits of life, whereas reactive power turns against itself such as actions of revenge or affections of fear and resentment. Reactive power is also present in forms of domination that deprive and control.

We see here a posthuman subjectivity which participates in life-giving powers related to 
its own desires and passions and driven to become different from and more than what is allowed in neoliberal forms of subjectification.

\section{Becoming}

The monistic ontology of becoming refers to the powers that flow through everything. The effect of the powers is the ongoing process of increasing complexity and diversity. These processes of becoming are a feature of being itself. Becoming is a positive life-force or zoe which refers to the endless vitality of life (Braidotti 2006, 41). 'Becoming' refers to the dynamic un/enfolding of reality through the nonhuman 'vitality of matter' (Bennet 2010). It rests on an understanding of matter as intelligent and self-organising (Braidotti 2006, 35). Life and intelligence, as anything else that exists, are effects of these processes of becoming.

Becoming is not only to come into existence, but also to become many and different, to become multiple. The relation between becoming multiple and becoming different is expressed as follows:

A multiplicity is defined not by its elements, nor by a center of unification or comprehension. It is defined by the number of dimensions it has; it is not divisible, it cannot lose or gain a dimension without changing its nature. (Deleuze and Guattari 1987, 249).

All becoming is also becoming-minoritarian. Since 'majority' assumes power, domination and sameness, minoritarian is associated with becoming itself, with multiplicity, creativity and difference. Becoming-animal, becoming-woman, becoming-imperceptible are examples of becoming-minoritarian since they realise modes of being that stand in opposition to the singular and the dominant. They are becomings which do not establish a norm for all. It is not possible to become-man since 'man' is the majority par excellence in the sense of providing a dominant singular standard (Deleuze and Guattari 1987, 291) and is therefore the opposite to becomingminoritarian.

Becoming always takes place through assemblages (or associations). It is a becoming with others described by Barad (2007) as 'intra-actions’. Intra-action differs from inter-action in the sense that it does not assume the pre-existence of entities. The different entities (relata) do not precede the relations but are constituted in the process of relating. Becoming is therefore relative to and contingent on the particular forces involved.

This dynamic process of becoming is captured by the tropes nomad and rhizome. Becoming is like a rhizome since it spreads in any direction from any point. According to Springgay (2008) a rhizome is an 
assemblage that moves and flows in dynamic momentum. The rhizome operates by variation, perverse mutation, and flows of intensities that penetrate meaning .... It is an in-between space, open and vulnerable, where meanings and understandings are interrogated and ruptured.

Becoming through associations is a positive, life-affirming process as testified to by Shildrick and Price (2005, point 17) in relation to the disabled:

The interpersonal care and assistance that I experience and that shapes my becoming [as a disabled woman] is situated in a rhizomatic proliferation of connections, in nodular social networks coalescing in temporary points of assemblage, that profoundly reshape all our identities and ultimately the dimensions of the worlds we inhabit.

Becoming-imperceptible (Deleuze and Guattari 1987, 232) is to be part of multiple connections where a fixed identity disappears and where subjectivity is enhanced through multiple connections. Subjectivity is enhanced when it is subjected to the affects of others and where it could participate in ongoing and unpredictable becoming.

The subjectivity of becoming-different and -multiple is in opposition to the sameness imposed by neoliberal forms of governmentality. It is the kind of becoming that cannot be normalised and controlled within a regime of power.

\section{Desire and affect}

The multiplicity and unpredictability of becoming is caused by the operations of desires and affects. The desire to become is the primary life force. This conception of desire as productive is in contrast with the way it is understood as an insatiable lack in Psychoanalysis. Since the Oedipal desire has to be repressed in order for the ego to be socialised, individual and social repression are closely related (Freud 1962). Olsson $(2009,145)$ draws on posthuman theories to describe the relation between individual and social repression within this view of desire. If desire is seen as a lack, children or 'mad people' are seen as needy. In this case desire is not seen as something through which reality could be produced, but rather as the symptom of need and lack. This view deprives 'mad people' and children of the positivity of their desires and adapts them to the power of the institution.

Since desire is seen as the primary life force, it does not function on the basis of lack, but is a pre-individual force that produces wants and interests. Desire-production is not only an individual force but a social force. Desire-production refers to the unconscious production of the real (Deleuze and Guattari 1983, 26, 30, 49). The production of the real through desire is the construction of an assemblage, as stated by Deleuze: 'For me, anytime somebody says that they desire something it means that he is about to construct an assemblage' (Deleuze translated by Olsson 2009, 149). 
Affect is necessary for desire to be realised since assemblages are constructed through the mutuality of affect. The power to affect others is, for Spinoza, related to the power to be affected (Hardt 2007, x). Affect does not simply refer to external relations of cause and effect, but to the ways the humans and nonhumans are changed in assemblages. Braidotti $(2006,148)$ describes this relatedness among subjectivities as 'the force that aims at fulfilling the subject's capacity for interaction and freedom'. Affect is the unformed potentia that is expressed in joyous ways. It should not be equated with feelings and emotions because it is pre-personal and pre-rational. Shouse (2005, par. 5) points to the ways the body increases the intensities and scope of its capacities through the affects of its many encounters.

Desire and affect are not only positive forces since they could become oppressive as in Fascism and they could be derailed as in Capitalism. Deleuze and Guattari $(1983,257)$ describe Fascism as the desire for the power to suppress diversifying desires and to reproduce the same through isolated subjectivity. Capitalism, on the other hand, operates on the basis of an insatiable lack, which it promises to fulfil through the consumption of commodities. In this way the productive force of desire is captured in a spiral of pre-existing lacks and satisfactions (Deleuze and Guattari 1983, 245). There is a permanent danger for desires to be distorted and derailed.

While the 'post' in posthumanism points to the death of the human subject and the end to human exceptionalism, it is not an antihuman denial but rather an assertion of the particularity, capacities and freedom of the human. While the human subject is not in control of his/her own destiny, she/he has an important role in the becoming of the world as described in a posthuman ethics.

\section{TOWARDS A POSTHUMAN ETHICS}

A pedagogy of social justice rests on ethics. A posthuman approach to ethics guards against the individual and social derailments of desire and affect. It is not so much an ethics that claims rights and justice, but rather one that enhances and enables all to participate in the ongoing and unbounded processes of becoming.

A posthuman ethics accepts a decentred subjectivity which is part of and responds to the unfolding of events. Events precede for Deleuze the subject and provide the ethical challenge:

To the extent that events are actualized in us, they wait for us and invite us in .... Everything was in order with the events of my life before I made them mine; to live them is to find myself tempted to become their equal, as if they had to get from me only that which they have that is best and most perfect ... Either ethics makes no sense at all, or this is what it means and has nothing else to say: 'not to be unworthy of what happens to us'. (Deleuze 1990, 148 ,9). 
Ethics is a response to the unfolding of events in such a way that we live up to the challenges and possibilities to enhance subjectivity.

Ethics describes a certain mode of becoming as a particular way of existing in the world with others. At an ontological level it refers to the co-existence with many others which include nonhuman and 'non-living' things such as material objects and technologies. At a conscious level it entails the recognition of the multiple connections and dependencies between the self and others. The 'mode of becoming' is an ethics of existence in pursuit of a good defined by the responsibility for and obligation towards the other. At an affective level it refers to the powers to affect and to be affected.

We are confronted with the ethical question of how to respond to the unfolding of events in our attempt to transform ourselves and the world. The ethical good is not necessarily to be found in universal values such as human rights, freedom and equality but rather in the quality of the ongoing process of becoming defined by the positive and creative working of powers. Whatever promotes the joyful and creative flow of powers (potentia) is an ethical good and what is to be avoided is the kind of power (potestas) that stops these flows. Ethics entails faithfulness to, enhancement and perseverance of this potentia, the desire to become and to express freedom (Braidotti 2006, 148, 163). According to Braidotti $(2006,148)$ it is 'conducive to ethical behaviour only if the subject is capable of making it last and endure, thus allowing it to sustain its own impetus. Unethical behaviour achieves the opposite: it denies, hinders and diminishes that impetus, or is unable to sustain it'.

The ethical could be compared with good and bad habits in relation to making connections and becoming other and different. Hroch $(2014,65)$ explains that good habits are connections that work 'by sustaining intensities through generating difference'. Bad habits 'eradicates differences, creates monotonies and monopolies, and diminishes intensities - the potential to further regenerate by generating difference’.

Ethics is also an evaluation in relation to the value of the affects. Instead of an ethical judgement that draws on universal values, ethics is an 'immanent evaluation' of 'every being, every action and passion, even every value, in relation to the life they involve'. To evaluate is based on the affective tone of “I love or I hate” instead of I judge' (Deleuze 1989, 141). The principle of evaluation is whether the life involved constitutes an ethical good defined in terms of the enhancement of affects, the capacity of the body to increase its intensities, and subjectivity as becoming-minoritarian. The expansion of affect through assemblages is an ethical good because it increases the freedom to become. 


\section{PEDAGOGY FOR SOCIAL JUSTICE}

A posthuman ethic informs pedagogical practices for social justice. Pedagogy is the intentional educational process which aims the kind of learning that enhances a mode of becoming. The mode of becoming-minoritarian is the participation in the ongoing forces of differentiation through connections. Learning to become is the search for ways to connect and to multiply. This is different from cognitivist approaches to learning since consciousness cannot be separated from its embodied entanglements. The change brought about by learning does not start with a changed consciousness but with the assemblages and events of which consciousness is an effect. Learning is an embodied experience through which signs and events are recognised for their possibilities to become. Pedagogy therefore entails the expansion and intensification of the assemblages within which the student is being connected. As a result, 'learning' always takes place in and through the unconscious, thereby establishing the bond of a profound complicity between nature and mind (Deleuze 1994, 165). Learning originates from something in the world that forces us to think (Deleuze 1994, 139). These encounters enable the body 'to expand or increase the array of bodies, objects and entities it may affect and be affected by' (Duff 2013, 195).

Pedagogy enables the enhancement of the mode of becoming through the expansion and intensification of relations. The intensity of learning refers to the multiple ways in which the self affects and is affected by others. Due to the importance of this intensity, the relation with others is not instrumental, since the very 'essence' of the self is constituted by others and the quality of the self is dependent on the nature of these relations.

A conception of the good is defined above in relation to the participation in the differential becoming of being. The ethical good lies in the enhancement of the powers to become different through the multiplication of affects. A pedagogy interested in social justice aims therefore at the inclusion of everyone and everything in these processes of becoming and in the expansion of relations with multiple others.

Duff's work is of particular interest to a pedagogy of social justice since she addresses the issues of the inclusion of the 'disabled' in relation to embodiment and assemblages. She describes an affective pedagogy as a 'shock' where the body is opened to becoming different. The body is 'recomposed' and subjectified when affected by new forces, relations and concepts. In the process the body grows in its capacity to affects and be affected (Duff 2013, 194, 199).

This posthumanist account of a pedagogy for social justice builds on and expands the work of various authors. Strom and Martin (2013) show how a pedagogy of social justice is an ongoing process of self-reflection on the effects of pedagogical practices. This reflection aims 
to enhance the possibilities to become different in the light of the unpredictability of these effects. Goodley $(2007,328,9)$ identifies, in relation to the disabled, six aspects of a pedagogy aiming to promote social justice. Among these are the interconnection of bodies, an acknowledgement that students are already desire-productive, the development of new sensibilities for all involved and experimentation with a caring pedagogy of becomings. Grellier (2013) shows how rhizomatic analysis could open up issues of learning spaces in a higher education institution, and how voice could be given to marginalised groups. Although social justice is not the primary concern in Olsson's view, she provides a rich Deleuzian analysis of the becomings of pre-schoolers. She comments on the effect of the one-sided focus on goals and outcomes in pre-school education on those children who are not equally able to decode and adapt to the system. This is highly relevant to a pedagogy for social justice in higher education characterised by a pedagogy of predetermined outcomes and students who experience difficulties with decoding the dominant forms of knowledge. Olsson explains the importance of desire construction for a pedagogy for social justice below.

... these children have probably been cut off in their desires; they have for one or another reason not been able to connect their lines of flight to other lines. Or maybe they live a construction of sense and problems that seems very far from established facts about the world. Working with the production of desire, sense and problems could be very beneficial for these children. (Olsson 2009, 187).

What follows is an elaboration of some aspects of a pedagogy for social justice in conversation with these views.

\section{Desire and affect}

A pedagogy for social justice fosters affect, desire and enjoyment. While issues of social justice are usually cast in terms of redress, passivity, deprivation and lack, a posthuman approach focuses on the abilities and opportunities to be part of and to respond to unfolding events. It enhances the desire to become and the enjoyment of participating in the powers of transformation. It therefore requires a shift from the subject in need of upliftment, therapy and charity to one of joyful participation on the basis of its own desire-production. A pedagogy of affect also displaces the primacy of cognition and the acquisition of knowledge (Zembylas 2007, 19, 20). Olsson $(2009,133)$ describes in rich detail such a pedagogy of desire and experimentation when pre-schoolers play with an overhead projector (OHP), costumes, light and shadows. In the process they demonstrate the productive force of desire and the power of multiple affects. It transpires from these experiments how the marginalised are already producers of desire through which they respond to the unfolding of the events in which they are 
immersed.

Such a posthuman pedagogy of social justice responds to the way desire is often produced and 'satisfied' in higher education. Students are projected as in need of upliftment, of a qualification and as lacking epistemological access (Morrow 2007). The induced desire around such lacks could only be provided by the institution. This construction of the lack tames their desire to become different and it contributes to individual and social repression. A focus on lack fulfilment through the recognition of diversity is commented on by Goodley (2007, 322). The discourse of diversity emphasises different identities and ignores 'viewing humanity - and critical pedagogy - as emergent activities'. The accommodation of designated groups and the framing of the possibilities of diversity curtail the desire to become different.

In contrast to these kinds of curtailment, the unpredictability and uncontrollability of becoming through desire-production should be enhanced through the intensification and expansion of opportunities to be affected. In order for governments and higher education institutions to respond meaningfully to student protests, they have to engage with their desire production. It cannot be assumed that students desire what neoliberal institutions offer such as the promise of assimilation into a dominant order or the acquisition of dominant forms of knowledge. To engage with desire production is to provide the conditions within which students could experiment with possibilities of becoming in relation to dominant and marginalised knowledge traditions. It cannot be expected that these desires would be clearly articulated as a precondition for such engagement. What will be important is the provision of the spaces (Grellier 2013) for desires to emerge and to contribute towards the production of different realities. Instead of creating and attempting to fulfil desires, a pedagogy for social justice should experiment with the desire-production in different assemblages.

A pedagogy for social justice creates opportunities for the desires to become different, to affect others and to be affected by them. Opportunities have to be created for students to express themselves freely without fear of being labelled or silenced, to organise and assemble freely in order to experiment with their desire-productions and to increase their affects. Students have to be exposed to multiple possibilities of becoming through opportunities to read and write. The opportunities to affect and be affected are not only provided for in the classroom, but also in the way students protest, organise and intervene in the world. Being a student is partly to withdraw from the world into safe spaces of experimentation, but it is also to become part of the unfolding of experiments of equality, freedom and dignity.

\section{Becoming minoritarian}


To become-minoritarian is to escape from the predefined categories of identity presented as an inheritance, a social order or a choice. Becoming-minoritarian expresses the desire to become different in an own way. This is not a one-sided emphasis on individuality, but a recognition of how individuation relates to multiple connections.

A pedagogy for social justice is a pedagogy for all and not only for the marginalised. The becoming other, becoming-minoritarian and becoming-imperceptible are equally applicable to all. The 'majority' (in the sense of the dominant) is as much caught up in the distorted production of desire and the suppression of differences as are the marginalised minorities. A pedagogy for social justice offers the marginalised the opportunity to act on their different imagining of the world and to connect their lines of flight to other marginalised lines. It offers the dominant majority by providing the opportunity to become minoritarian through connections with the multiple others.

Becoming-minoritarian is not served by predefined learning outcomes that standardises learning and promotes conformity. A pedagogy for social justice accepts that what a student could become cannot be known beforehand (Springgay 2008, 11). In relation to the use of games in early childhood education, Sørensen (2011) explains that the kinds of games could make a difference between 'becoming-towards-an-end and becoming-without-an-end'. This applies also to higher education where the first kind of becoming limits the agency of students to predefined outcomes, and the second kind of becoming opens their future in a time of flux and complexity.

The becoming different is enabled by learning without predefined outcomes in relation to problems and the production of meaning. Olsson $(2009,182)$ names this approach to learning the 'art of constructing a problem'. This openness of problematising relates to Olsson's comments that the 'body of knowledge in this project is acting according to Spinoza's logic; we do not yet know what a body can do ... we do not yet know what a child can do and we do not yet know what an overhead machine can do’ (Olsson 2009, 174). The openness of becoming is for Strom and Martin (2013) made possible through journal writing and reflection. They (2013, 226) define the classroom as ‘a site of perpetual transformation' of both educators and students who connect with their histories, local communities, course materials and policies.

Social justice is served when students are enabled to enhance their opportunities to become a different self, different from any predefined identity or an evaluative order. While higher education inevitably contains elements of vocational training, we ultimately do not know what a professional is or can do. 


\section{Connections}

The opportunities to become-minoritarian are given to students by multiplying connections and exploring their assemblages. Since the desire and power to become-other are produced by assemblages students should become rhizomes and nomads. As rhizomes they continually explore new associations and as nomads they refuse fixed destination or static relations.

The illustration by Olsson of how pre-schoolers connect with each other, an OHP, light and shadows in their joyful exploration and discovery of themselves, could inform higher education pedagogies by showing how an openness to the agential roles of materialities such as electronic devices induces the becoming-cyborg of students (Gough 2004). Like the preschoolers they could produce realities where affects such as excitement and caring are enhanced through the extension and intensification of connections within study and reading groups or in relations with their communities.

The powers to affect and to be affected are enhanced through the multiplication of assemblages and associations. It is an openness to be affected which enhances the powers to affect. Olsson $(2009,187)$ comments on the main task of a pedagogy for social justice: 'The only thing one can do is to create more space for desiring bodies to expand their capacities'.

While Duff's investigation centred upon the social inclusion of people living with mental illness, the same pedagogy could be used in relation to people who are otherwise excluded on the basis of class, 'race’, etc. Duff $(2013,205)$ makes a valid point when she suggests that social inclusion is enabled through the 'enactment of affective and relational connections between subjects, bodies, places and milieus' where it is made possible for the subject to discern the 'signs and events' of inclusion ... and then harness them in their own 'becoming well' (Duff 2013, 205). Students should never be seen as victims of circumstances since they are always able to work with forces in an active (versus a reactive) way.

The expansion and intensification of connections could take place in different ways in higher education. This already happens in the kinds of service learning based on the reciprocity of learning and knowledge construction (Mitchell 2008). It could also happen through collaborative forms of learning where relations are not instrumental to the acquisition of private forms of knowledge. Connections could also be enhanced through the shared world of lecturers and students that respects the equal contribution to make sense of the world (Rancière 1991). The nomadic and rhizomatic student is not bound by disciplinary or institutional boundaries in search for different interests and possibilities of becoming. A pedagogy that aims to increase connections and open up spaces to become enables students to pursue knowledges and relations across the university as a whole. 


\section{Responsibility}

The proximity within the connections induces responsibilities and obligations. The proximity calls up the unique face of the other, which cannot be ignored. The proximity brings an obligation to respond to the other and a relational awareness of how others are affected by the own mode of becoming.

Such a pedagogy of proximity could start with the tracing of assemblages the individual is involved in and on which the own lifestyle depends. This would show how the own mode of being is dependent on the labour and resources of multiple others, or how it contributes towards the privilege of others. This pedagogy could enable students to question and respond to the assemblages they are enrolled in as a beneficiary or a resource, such as particular knowledge traditions or technological networks.

This responsibility extends to nonhumans and the earth. Angus, Cook, Evans et al. ${ }^{1}$ (2001) illustrate the responsibilities and obligations a 'cyborg pedagogy' brings about. Students are enabled to trace their assemblages by starting with their daily coffee. The assemblage of making coffee is traced to coffee plantations in Brazil, milk farms in the country, the electricity supply networks, etc. The practice of making coffee is part of an assemblage which also consists of international trade agreements, labour practices in coffee plantations, the practices on milk farms and the networks of power supply. The tracing of these assemblages produces an awareness of the embodied relatedness of the 'individual' within networks of privilege and exploitation. A response to all the others is needed. The cyborg pedagogy illustrates the precariousness of a shared life and how the obligation towards the others in the assemblage is an essential part of a sustainable life and where the becoming-other is related to the becomingwith-the-other. Responsibility for the other is not separated from the desire to become through connections with others.

The tracing of their multiple assemblages alerts students to the multiple ways they are already affected by multiple others. Such awareness of responsibilities enhances the transformative effects of connections. It is therefore important for a pedagogy of social justice to assist students to realise what and whom they are responsible for.

\section{CONCLUSION}

The discussion aimed to provide an illustration of some ways how a posthuman pedagogy could contribute towards social justice. A pedagogy for social justice challenges the perceived 
deficiencies and dangers to humanity and the earth associated with difference and desire. It shows that the cultivation of the desires to become different is important for a people and an earth 'yet to come' (Conio 2015) beyond the war against humanity and the earth waged in the name of such people.

This is a pedagogy for all in the sense that it does not simply aim to 'empower' the powerless and 'inform' the privileged of social injustices. It points to the ways the desires of everyone could be distorted and manipulated to curtail difference and to promote the same. A pedagogy for social justice does not focus on empathy, compassion, charity, care or equality where the other is treated as deficient in some way. These pedagogies may too easily lapse into the certainty of the knowledge of who the other is and what they need. The emphasis should rather be on the creation of the conditions which could enhance the ability of everyone to produce their own desires, to make their own connections and to become different.

The pedagogy for social justice is simultaneously a pedagogy for a sustainable future because it affirms the connection with the earth as the condition for life and difference. The kind of life the earth could sustain is one where dependencies and interconnections are recognised. Colebrook (2015, 21, 2) argues for a 'minor politics' that would 'intensify forces that are irreducible to the state ... disentangling life on earth from the striated space of East and West'.

A pedagogy of social justice intervenes in the production of student subjectivities by reinforcing the desires to become other, which could be detected in recent protest movements. This intervention asserts the desire to become which exceeds the reach of neoliberal forms of subjectification. It searches for and exploits opportunities to enhance and intensify the unpredictable and uncontrollable desires to become with others. While this pedagogy is based on critiques of the neoliberal subjectivities of individualism, competitiveness and accumulation, it has to remain open to multiple and new forms of becoming minoritarian. It is therefore essential for this pedagogy to be attentive to the new (Arendt 1998) that emerges from protests and revolutions and to be perceptive about the ways desires are quickly perverted into majoritarian forms of control and repression. It is a pedagogy that goes beyond protest and towards the construction of a different world.

\section{NOTE}

1. 'et al.' refers appropriately to the multiple (heterogeneous) others that contributed to the article.

\section{REFERENCES}

Alexander, N. 2014. Universities and the 'knowledge economy'. In Education, Economy \& Society, ed. 
S. Vally and E. Motala, 48-56. Pretoria: Unisa.

Angus, T., I. Cook, J. Evans, et al. 2001. A manifesto for Cyborg pedagogy? International Research in Geographical and Environmental Education 10(2): 195-201.

Apple, M. 2006. Educating the 'right' way: Markets, standards, God and inequality. 2nd ed. New York: Routledge.

Arendt, H. 1998. The human condition. Chicago: University of Chicago Press.

Balibar, E. 1997. Spinoza: From individuality to transindividuality. A lecture delivered in Rijnsburg on 15 May, 1993. Delft: Eburon.

Ball, S. J. 2013. Foucault, power and education. New York: Routledge.

Ball, S. J. 2015. Subjectivity as a site of struggle: Refusing neoliberalism. British Journal of Sociology of Education. doi:DOI: 10.1080/01425692.2015.1044072.

Barad, K. 2007. Meeting the universe halfway. Quantum Physics and the entanglement of matter and meaning. Durham, NC: Duke University Press.

Barnett, R. 2003. Beyond all reason. Living with ideology in the university. Buckingham, UK: Open University Press.

Bennet, J. 2010. Vibrant matter: The political ecology of things. Durham, NC: Duke University Press.

Bennet, T. and P. Joyce, eds. 2010. Material powers: Cultural studies, history and the material turn. Oxon: Routledge.

Berlin, I. 1984. Two concepts of liberty. In Liberalism and its critics, ed. M. J. Sandel, 15-36. New York: New York University Press.

Bok, D. 2003. Universities in the marketplace. The commercialization of higher education. Princeton: Princeton University Press.

Braidotti, R. 2006. Transpositions. On Nomadic ethics. Cambridge, UK: Polity Press.

Carrington, S. 2011. Service-learning within higher education: Rhizomatic interconnections between university and the real world. Australian Journal of Teacher Education 36(6): 1-14.

Chetty, N. and C. Merret. 2014. The struggle for the soul of a South African university. The University of Kwazulu-Natal: Academic freedom, corporatisation and transformation. Self-published. http://soul-of-ukzn.co.za/images/downloads/UKZN-BOOK.pdf.

Colebrook, C. 2015. Preface. In Occupy. A people yet to come, ed. A. Conio, 9-22. London: Open Humanities Press.

Cole, D. 2011. Matter in motion: The educational materialism of Gilles Deleuze. Educational Philosophy and Theory 43(6): 1-13.

Conio, A., ed. 2015. Occupy. A people yet to come. London: Open Humanities Press.

Coole, D. and S. Frost. 2010. New materialisms: Ontology, agency, and politics. Durham, NC: Duke University.

Deleuze, G. 1989. Cinema 2: The time image. Translated by H. Tomlinson and R. Galeta. Minneapolis: University of Minnesota Press.

Deleuze, G. 1990. The logic of sense. (Original Published in 1969). Edited by C. V. Boundas. Translated by M. Lester. New York: Columbia University Press.

Deleuze, G. 1994. Difference and repetition. New York: Columbia University Press.

Deleuze, G. 1995. Negotiations. Translated by M. Joughin. New York: Columbia University Press.

Deleuze, G. and F. Guattari. 1983. Anti-Oedipus. Capitalism and schizophrenia. Translated by R. Hurley, M. Seem and H. R. Lane. Minneapolis: University of Minnesota Press.

Deleuze, G. and F. Guattari. 1987. A thousand plateaus. Capitalism and scizophrenia. Translated by B. Massumi. Minneapolis: University of Minnesota Press.

Duff, C. 2013. Learning to be included. In Cartographies of becoming in education. A Deleuze-Guattari 
perspective, ed. D. Masny, 193-208. Rotterdam: Sense Publishers.

Foucault, M. 1982. The subject and power. Critical Inquiry 8(4): 777-95.

Foucault, M. 2007. What is critique? In The politics of truth, by M. Foucault, ed. S. Lotringer, translated by L. Hochroth and C. Porter, 41-81. Los Angeles: Semiotext(e).

Freud, S. 1962. Civilization and its discontents. Translated by J. Strachey. New York: W. W. Norton.

Giroux, H. A. 2014. Neoliberalism's war on higher education. Chicago: Haymarket Books.

Goodley, D. 2007. Towards socially just pedagogies: Deleuzoguattarian critical disability studies. International Journal of Inclusive Education 11(3): 317-34.

Gough, N. 2004. RhizomANTically Becoming-Cyborg: Performing posthuman pedagogies. Educational Philosophy and Theory 36(3): 253-65.

Grellier, J. 2013. Rhizomatic mapping: Spaces for learning in higher education. Higher Education Research \& Development 32(1): 83-95.

Haraway, D. 2015. Anthropocene, Capitalocene, Plantationocene, Chthulucene: Making kin. Environmental Humanities 6: 159-65.

Hardt, M. 2007. Foreword: What affects are good for. In The affective turn. Theorizing the social, ed. P. T. Clough and J. Halley. Durham: Duke University Press.

Higgins, J. 2013. Academic freedom in a democratic South Africa. Essays and interviews on higher education and the humanities. Johannesburg: Wits University Press.

Hroch, P. 2014. Deleuze, Guattari, and environmental pedagogy and politics: Ritournelles for a planetyet-to-come. In Politics and education. For a people yet to come, ed. M. Carlin and J. Wallin. New York: Bloomsbury.

Latour, B. 2004a. The politics of nature: How to bring the sciences into democracy. Cambridge, MA: Harvard University Press.

Latour, B. 2004b. Why has critique run out of steam? From matters of fact to matters of concern. Critical Inquiry 30: 225-48.

Lyotard, J-F. 1984. The postmodern condition. A report on knowledge. Translated by G. Bennington and B. Massumi. Manchester: Manchester University Press.

Macrine, S., P. McLaren and D. Hill, eds. 2010. Revolutionizing pedagogy. Education for social justice within and beyond global Neo-Liberalism. New York: Palgrave MacMillan.

McGettigan, A. 2013. The great university gamble. Money, markets, and the future of higher education. London: Pluto Press.

Mitchell, T. D. 2008. Traditional vs. Critical service-learning: Engaging the literature to differentiate two models. Michigan Journal of Community Service Learning 14(2): 50-65.

Morrow, W. 2007. Learning to teach in South Africa. Pretoria: HSRC Press.

Olsson, L. M. 2009. Movement and experimentation in young children's learning. Deleuze and Guattari in early childhood education. London: Routledge.

Rancière, J. 1991. The ignorant schoolmaster. Five lessons in intellectual emancipation. Translated by K. Ross. Stanford: Stanford University Press.

Shildrick, M. and J. Price. 2005. Deleuzian connections and queer corporealities: Shrinking global disability. Rhizomes. Cultural Studies in Emerging Knowledge 11/12. http://rhizomes.net/ issue11/shildrickprice/index.html

Shouse, E. 2005. Feeling, emotion, affect. M/C Journal 8 (Dec).

Sørensen, E. 2011. Configuration of ontologies: An inquiry into learning designs. In Children, development and education, ed. M. Kontopodis, C. Wulf and B. Fichtner, 165-83. Dordrecht: Springer.

Springgay, S. 2008. An ethics of embodiment, civic engagement and A/R/Tography: Ways of becoming Nomadic in art, research and teaching. Educational Insights 12(2). 
Strom, K. J. and A. D. Martin. 2013. Putting Philosophy to work in the classroom: Using Rhizomatics to deterritorialize Neoliberal thought and practice. Studying Teacher Education 9(3): 219-35.

Zembylas, M. 2007. The specters of bodies and affects in the classroom: A Rhizo-ethological approach. Pedagogy, Culture \& Society 15: 19-35.

Zipin, L., A. Fataar and A. Brennan. 2015. Can social realism do social justice? Debating the warrants for curriculum knowledge selection. Education as Change 19(2): 9-36. 